\title{
Úlcera de abomaso em touro Nelore causada por parorexia: relato de caso
}

Wilmar Sachetin Marçal[a]", Rafael Gonçalves Dias ${ }^{[a, b]}$, Cassiano Kahlow ${ }^{[a, b]}$

[a] Universidade Estadual de Londrina (UEL), Londrina, PR, Brasil

${ }^{[b]}$ Agência de Defesa Agropecuária do Paraná, Curitiba, PR, Brasil

*Autor correspondente

e-mail: wilmar@uel.br

\section{Resumo}

Na pecuária bovina, a úlcera de abomaso é causa comum de hemorragias gastrintestinais, causando indigestão, melena e, algumas vezes, perfurações, resultando em peritonite local aguda, dolorosa ou difusa, e com morte súbita. Os fatores de risco são bem conhecidos e o processo de ulceração desenvolve-se quando a barreira mucosa, que protege o órgão, é afetada; ou, ainda, quando ocorre exacerbação dos fatores nocivos como hiperacidez, infecções e estresse. A taxa de letalidade nos animais acometidos por úlceras abomasais hemorrágicas pode chegar a $100 \%$ dos casos. No presente trabalho, relata-se a ocorrência de caso clínico de úlcera abomasal tipo IV, em um touro da raça Nelore PO, 25 meses de idade, pesando 847 kg. 0 bovino provavelmente desenvolveu essa patologia em decorrência de estresse e parorexia. 0 touro encontrava-se em uma exposição agropecuária em município do estado do Paraná e, após sua chegada, iniciou, subitamente, alteração comportamental. Paradoxalmente, começou a ingerir, de modo voluntário, a cama do pavilhão, constituída de cepilho de madeira, apesar de ter alimentação em qualidade e quantidade. A temperatura média do local era de $27^{\circ} \mathrm{C}$. No terceiro dia da Feira Agropecuária, o touro veio a óbito e foi removido para ser necropsiado. Descartou-se outras possibilidades que pudessem causar a morte do animal. No procedimento de necropsia foram observadas perfurações na região pilórica e curvatura maior do abomaso, com abertura de aproximadamente $3 \mathrm{~cm}$ de extensão, fluindo expressivo conteúdo abomasal. As pregas abomasais estavam edemaciadas, com presença de úlceras multifocais de tamanhos e formas variadas. Percebeu-se restos alimentares com a cama de cepilho ingerida pelo animal. Os achados foram condizentes com a literatura, pela maioria das úlceras encontradas na curvatura maior da região fúndica e na região pilórica. As úlceras observadas foram caracterizadas por ruptura da parede abomasal com derramamento extenso do conteúdo do abomaso na cavidade abdominal e consequente peritonite difusa. No 
contexto da etiopatogenia, os autores destacaram o estresse pela consequente mudança comportamental, induzindo a ingestão compulsiva da cama do pavilhão e o desencadeamento da ulceração de abomaso. As constantes viagens para exposições e a alteração de ambiente foram desencadeadores desse estresse. Essa alteração metabólica pode aumentar a liberação de corticóides endógenos que produzem maior secreção de ácidos e pepsina no abomaso, favorecendo a formação das úlceras. Alguns buiatras orientam para que haja menor fluxo de transporte e exposição de animais, além de profilaxia no manejo, sendo os bovinos alojados em ambientes confortáveis, protegidos do calor e do frio, com sombra, água e alimentação de qualidade à disposição. A úlcera de abomaso se faz presente na rotina clínica dos ruminantes, decorrente de falhas no manejo nutricional e sanitário, sendo de difícil diagnóstico no início da doença e de evolução rápida, o que causa transtornos clínicos graves e óbito. 